DOI: $10.25178 /$ nit.2019.1.4

\title{
«Смерть ближе рубашки»: похоронная обрядность старообрядцев-часовенных"
}

\author{
Елена С. Данилко
}

Институт этнологии и антропологии им. Н. Н. Миклухо-Маклая РАН, Российская Федерация

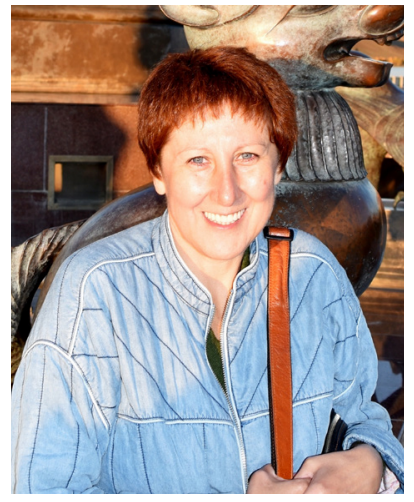

В статье анализируется похоронно-поминальный комплекс современных старообрядиев-часовенных, проживающих в Туве (Россия), в г. Нукус, Турткуль и близлежащих поселениях (Республика Каракалпакия, Узбекистан), а также в г. Тараз и пос. Рыбзавод (Жамбыльская область, Казахстан). В основе статьи лежат авторские полевые материалы, собранные во время экспедиций в 2014-2016 г. в Средней Азии и в 2018 г. в Туве. Приводятся выдержки из интервью с информантами.

Умирающего часовенные стараются вовремя исповедовать и причастить при помощи Великой («богоявленской», «крещенской») воды. Свечи, зажигаемые рядом с покойным, используются самодельные, из пчелиного воска, изготовление которых контролируется духовными лицами. Предпочтительнее использование для покойного домотканого полотна из натуральных материалов. Нередко в большинстве исследованных групп хоронят и в обычной, но обязательно новой одежде. У тувинских старообрядцев бытует более аскетичный архаичный комплект, не включающий сарафана и штанов. Как отличительный старообрядческий признак обязательно называется саван. Нательный крестик покойного также должен быть обязательно новым. Ни одна из деталей смертной одежды не должна завязываться на узел. Отмечается традиция пеленать покойного. Обмывание - процедура скорее символическая. Тело укладывают на лавку в красном углу, сначала головой к иконам, затем, когда оно перекладывается в гроб, лицом к ним.

У тувинских часовенных до сих пор хоронят в гробах, выдолбленных из цельного ствола дерева - «домовинах». У уральцев (часовенных Средней Азии) используют гробы из досок, но как некий показатель их больщей или меньщей «правильности» отмечается соединение деталей ящика «на деревянных шипах», то есть без гвоздей. Могилу, как правило, также копали уже непосредственно перед похоронами. Исследовались вопросы внутренней готовности старообрядцев к смерти, определявщей образ жизни человека и то, какими окажутся его проводы в последний путь.

Обрядовые практики, способы организации кладбищенского пространства, артефакты и символы обнаруживают важный для рассмотренных старообрядческих сообществ арсенал маркеров, сигнализирующих об актуальной на данный момент групповой границе, дифференцирующей и интегрирующей одновременно. При неизбежности бытовых контактов с окружающим населением старообрядцы стараются максимально оградить от внешнего влияния ритуальную сферу и связанные с ней объекты.

Ключевые слова: старообрядчество; часовенное согласие; похоронно-поминальная обрядность; групповые границы; Тува; Узбекистан; Казахстан

* Работа выполнена в рамках проекта РНФ № 18-18-00082 «Умершие в мире живых: кросс-культурное исследование коммуникативных аспектов танатологических практик и верований».

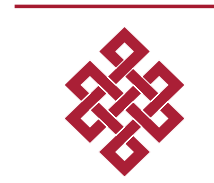

\section{Для циитирования:}

Данилко Е. С. "Смерть ближе рубашки": похоронная обрядность старообрядцев-часовенных [Электронный ресурс] // Новые исследования Тувы. 2019, № 1. URL: https://nit.tuva.asia/nit/article/view/829 (дата обращения: дд.мм.гг.). DOI: 10.25178/nit.2019.1.4

Данилко Елена Сергеевна - доктор исторических наук, главный научный сотрудник, заведующая Этнографическим научно-образовательным центром Института этнологии и антропологии им. Н. Н. Миклухо-Маклая РАН. Адрес: 119991, Россия, г. Москва, Ленинский пр-т, д. 32А, каб. 1810. Тел.: +7 (495) 938-18-20. Эл. адрес: Danja9@yandex.ruＯRCID:0000-0002-4231-4759

Danilko Elena Sergeevna, Doctor of History, Chief Research Fellow and Head, Ethnographic Research and Educational Center, N. N. Miklouho-Maclay Institute of Ethnology and Anthropology, Russian Academy of Sciences. Postal address: 32A Leninsky Ave., Moscow, 119991 Russia. Tel.: +7 (495) 938-18-20. E-mail: Danja9@yandex.ru 


\title{
«Death is closer than a shirt»: Funeral ceremonialism of Chasovennye ("Chapel-going”) Old Believers"
}

\author{
Elena S. Danilko \\ N. N. Miklouho-Maclay Institute of Ethnology and Anthropology RAS, \\ Russian Federation
}

The article analyzes the funeral and memorial complex of contemporary Old Believers of the Chasovennye ('chapel-going') type, living in Tuva (Russia); in Nukus, Turtkul and nearby settlements (Republic of Karakalpakia, Uzbekistan); and in Taraz and the village of Rybzavod (Zhambyl region, Kazakhstan). The article is based on the author's field materials collected during the 2014-2016 expeditions to Central Asia and the 2018, to Tuva. Also provided are some excerpts from interviews with the informants.

The Chasovennye try to confess and commune the dying person in time, using the Great agiasma (Holy water of the Epiphany). Near the body of the deceased, they light hand-made candles of beeswax, the production whereof is controlled by clergymen. In dressing the body, it is preferable to use homespun fabric made of natural materials. In most of the communities studied, the dead may be buried in regular clothes, but always unworn. Tuvan Old Believers have a more austere and archaic outfit in which sarafan and pants are not included. The shroud is a necessary distinctive feature of Old Belief funeral. The baptismal cross of the deceased must also be new. None of the burial clothes can use knots. A tradition to swaddle the deceased has also been observed. Ablution is a rather symbolic procedure. The body is placed on a bench in the 'red corner', first with its head to the icons, then facing them, when it is transferred to the coffin.

The Tuvan Chasovennye still bury their deceased in the coffins carved from a solid tree trunk, which are called "domovina". The Uraltsy (Chasovennye living in Central Asia) may use coffins made of planks, but an indicator of their greater or lesser "correctness" is how parts of the coffin are joined together "with wooden spikes", that is, without nails. As a rule, the grave is dug right before the funeral. In the article, we also examine the issues on Old Believer's internal preparedness to death - an event defining the person's life and the nature of the farewell ceremony.

Ritual practices, an organization of the cemetery space, artifacts and symbols - all of these are considered important markers for the Old Believer communities, indicating the current group boundary, which differentiates and integrates it at the same time. With the inevitability of contacts with the surrounding population, the Old Believers try to protect their ritual sphere and related objects from external influence.

Keywords: Old Belief; Chasovenny creed; funeral and memorial ritualism; group boundaries; Tuva; Uzbekistan; Kazakhstan

* The Article has written as part of RSF-supported project No. 18-18-00082 «Deceased in the world of living: cross-cultural study of the communicative aspects of thanatological practices and beliefs».

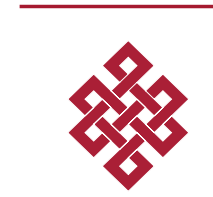

For citation:

Danilko E. S. «Death is closer than a shirt»: Funeral ceremonialism of Chasovennye (“Chapel-going”) Old Believers. The New Research of Tuva, 2019, no. 1 [on-line] Available at: https://nit.tuva.asia/nit/article/ view/829 (accessed: ... ). DOI: 10.25178/nit.2019.1.4

\section{Введение}

Традиционная обрядность, связанная с похоронно-поминальным комплексом, является для современных старообрядцев непосредственным продолжением конкретных положений религиозного учения. Без разговора о похоронах, о смерти и наказании за грехи не обходится ни один разговор о вере. Именно размышлениями о посмертной судьбе души и тела нередко определяются важнейшие жизненные выборы, от перехода в «соборную» часть общины («братию») до переезда в город, где похороны по-старообрядчески превращаются в сложную проблему. Кроме того, как показывают мои полевые исследования, похоронный обряд, содержащий в себе целый набор предписаний и особенностей, интерпретируемых как «старообрядческие», служат для верующих еще и одним из способов обозначения границ своего сообщества и декларации собственной религиозной принадлежности. Именно на этот аспект изучения похоронно-поминального комплекса предполагается обратить внимание в настоя- 
щей статье, сопроводив описание этнографических фактов рассмотрением их существования в дискурсе, возникающем при обсуждении со старообрядцами темы о групповых различиях, значимости этих различий и способах их поддержания.

В основе статьи авторские полевые материалы, собранные во время экспедиций к тувинским старообрядцам, расселяющимся в Каа-Хемском кожууне Республики Тыва (Россия) и к староверам-уральцам в Республике Каракалпакии (г. Нукус, Турткуль и близлежащие поселения), входящей в состав Узбекистана, а также в Жамбыльской области Казахстана (г. Тараз и пос. Рыбзавод).

Сближающим фактором для этих групп служит принадлежность к одному старообрядческому направлению - часовенному согласию ${ }^{1}$, хотя исторические условия, в которых они находились в течение нескольких веков, существенно различались. Так, уральцы, высланные в конце XIX столетия в Туркестанский край, оказались в тесном поликультурном («иноверном») окружении, с которым должны были устанавливать активные контакты, тогда как для тувинских старообрядцев, образовавших компактные поселения в верховьях Малого Енисея, такие контакты имели гораздо меньшую степень интенсивности. Указанные сходство и различие делают любопытным сопоставление этих групп, хотя изначально оговорюсь, что тезис об изоляции как решающем факторе сохранения культурного своеобразия и групповых границ, как и большинству современных исследователей, не представляется мне бесспорным и однозначным. Неоднозначность же вытекает из самого понимания «границы».

Для настоящей статьи наиболее близкими в теоретическом плане являются сформулированное Ф. Бартом определение групповых границ, не как «суммы объективных различий», отделяющих одно сообщество от другого, но исключительно как «набора тех различий, которые сами люди считают значимыми» (Барт, 2006: 16). В этот набор могут включаться как воспринимаемые дифференциальные признаки, находимые представителями сообщества у себя или формулируемые извне (одежда, пища, занятия и т. п.), так и ценностные ориентации, и поведенческие модели. При этом «ни один из указанных видов культурного “содержания”, - как пишет Барт, - не вытекает непосредственно из дескриптивного списка культурных признаков или культурных различий», релевантность которых целиком зависит от самих акторов (Барт, 2006: 16). Такой подход позволяет рассмотреть современную ситуацию более гибко, не располагая изучаемые явления лишь по одной по оценочной шкале сохранности или утраты традиции.

\section{Поле: немного истории и географии}

Прежде чем перейти к изложению полевых наблюдений необходимо хотя бы кратко охарактеризовать само «поле». Поездка в составе комплексной экспедиции к часовенным, проживающим в с. Сизим и арбанах (поселках) Эржей и Ужеп Каа-Хемского кожууна состоялась осенью 2018 г., благодаря коллегам из Тувинского государственного университета. Образование здесь старообрядческих поселений, сначала заимочного типа, затем более крупных началось на рубеже веков XIX -XX вв. Этот процесс был тесно связан, с одной стороны, с разнонаправленными миграционными потоками русского населения, составлявшими хозяйственно-культурную колонизацию края, с другой - воплощал в себе отмечаемую исследователями конфессиональную специфику, выражавшуюся в стремлении старообрядцев к социально-бытовой изоляции (Стороженко, 2015: 131). Отдаленные от других населенных мест

\footnotetext{
1 Часовенное согласие - течение в старообрядчестве. Оставшись на длительное время без священников во время гонений при императоре Николае I к концу XIX в. часовенные перешли к беспоповской практике и стали управляться уставщиками, которые вели богослужение и совершали таинства (крещение, исповедь) в часовнях (отсюда - название). Термин «часовенные» был предложен Н. Н. Покровским и Н. Д. Зольниковой, однако сами исследователи отмечали его условность, т. к. не во всех группах он использовался как самоназвание (см. об этом: Покровский, Зольникова, 2002: 12-13). В частности, он не был принят у старообрядцев уральцев, хотя догматически они объединяются с другими группами часовенных, в т. ч. с тувинскими старообрядцами.
} 
старообрядческие заимки устраивались вдоль Малого Енисея (Каа-Хема - по-тувински), на сегодняшний день это уже довольно крупные поселения. Самым изолированным из трех исследованных по сей день остается расположенный за порогом Байбалык Ужеп, где едва ли не единственной неместной жительницей является приезжающая «на сезон» (учебный год) учительница. Этнический и религиозный состав двух других поселков, Эржея и особенно Сизима, уже не отличается однородностью, в них проживает несколько сотен человек, рядом расположены туристические базы. Несмотря на кратковременность указанной поездки, она оказалась чрезвычайно насыщенной: удалось провести около десятка интервью со старообрядцами, в которых затрагивались самые разнообразные темы, в том числе и вопросы, связанные с похоронно-поминальным комплексом. Полевые записи хранятся в личном архиве автора и публикуются впервые.

Материалы по похоронной обрядности старообрядцев-уральцев собирались в течение трех полевых сезонов (с 2014 по 2016 гг.) в Республике Каракалпакии (г. Нукус, Турткуль и близлежащие поселения), входящей в состав Узбекистана, а также в Жамбыльской области Казахстана (г. Тараз и пос. Рыбзавод). Уральцами называют себя потомки казаков-старообрядцев, высланных во второй половине XIX в. в Туркестанский край за отказ от принятия военной реформы. Ссыльные, которых насчитывалось по некоторым данным порядка семи тысячи человек, распределялись по разным азиатским местностям от Ташкента до Джулака, от Аулиеаты (совр. Тараз) до Нукуса (Судаков, 2011: 5-6). Необходимость освоения новых приемов хозяйствования, выстраивания взаимоотношений с соседями, и, одновременно, сохранения собственной идентичности, определявшие существование первых русских переселенцев в Туркестанский край, остаются актуальными и для их далеких потомков. Так, в 1990-е гг. начался обратный отток русского населения в Россию, снова активизировавший для части уральцев процессы социокультурной адаптации к изменившимся условиям существования. В настоящее время в большинстве исследованных поселений группы уральцев немногочисленны, от двух-трех до двадцати семей в разных местах. Некоторые полевые материалы, которые хранятся в личном архиве автора, уже были опубликованы, однако похоронно-поминальному комплексу специального внимания не уделялось (Агеева, Данилко, 2016; Данилко, 2016).

В соответствии с принятыми в современной антропологии этическими принципами, в статье не указывают имена информантов. В статье в случаях прямого цитирования записанных интервью указываются только год и место сбора материала, а также номер интервью, которым он обозначен в моем архиве.

\section{«По старине, без новых введений»: причащение пред смертью}

Внутренняя неоднородность старообрядчества, составляющегося из множества субконфессиональных групп (согласий), предопределила в числе других факторов и множество локальных вариантов развития традиционной обрядности. Так, постепенный переход часовенного согласия от поповского направления к беспоповскому ${ }^{1}$ сопровождался постоянным пересмотром канонических установлений и связанных с ними религиозных практик. Новосибирские ученые Н. Н. Покровский и Н. Д. Зольникова в своей фундаментальной монографии об уралосибирских часовенных отмечали, что «порядок печальной церемонии, сопровождающий уход старообрядца из жизни» (Покровский, Зольникова, 2002: 83), был предметом рассмотрения нескольких соборов (Екатеринбургского (1874 г.), Бийского (1887 г.), Минусинского (1975 г.)), но вырабатывался, в отличие от многих других вопросов, без разногласий. За его основу был

\footnotetext{
${ }^{1}$ Поповское (поповщина, поповщы) и беспоповское (беспоповщина, беспоповцы) - два основных направления в старообрядчестве. Разделение старообрядчества произошло после прекращения дораскольного священства, когда часть старообрядцев (беспоповцы) предпочла остаться без церковной иерархии, нежели принимать священников, переходящих к старообрядцам от господствующей церкви (поповцы).
} 
взят чин погребения в Иноческом требнике ${ }^{1}$, при этом иерея ${ }^{2}$ полностью заменял наставник. Исключение составляли лишь чтение ектений ${ }^{3}$ и молитв, читаемых священником. Трансформация чина производилась, конечно же, со ссылкой на книжные сочинения. Прежде всего, часовенные ориентировались на знаменитый памятник XII в. «Вопрошанию Кирикову», в котором обосновывались правила, смягчающие некоторые строгие требования во имя утверждения православной веры среди язычников (Покровский, Зольникова, 2002: 83). Такой выбор, безусловно, свидетельствует и о характеристике, которую и современные часовенные дают ситуации, в которой они живут, и об их собственной миссии охранителей истинной веры.

Умирающего часовенные стараются вовремя исповедовать и причастить. Причащение у них совершается Великой («богоявленской», «крещенской») водой, то есть взятой из реки накануне праздника Крещения и освященной во время службы. Новая вода «пополняется» старой, бережно хранившейся в течение всего года в моленной или в доме у наставника:

«Поновится, старая с новой, старая с новой, и каждый год, и каждый год. Пополняется. Это

Великая вода называется. < > Малой водой не исправляют у нас, только Великой» (Полевые материалы, далее - ПМ, 2018. Сизим, интервью 2).

Такая практика закрепилась у часовенных уже с конца XIX в., когда они перестали принимать беглых священников. Это был один из самых дискутируемых вопросов на соборах. Помимо решения использовать церковный чин причащения преждеосвященными Дарами «вборзе» (т. е. в экстренной ситуации) и Богоявленской водой, символизировавшей кровь Господню, необходимо было обосновать возможность принятия причастия из рук мирян (Покровский, Зольникова, 2002: 80). Крошечные частицы даров, оставшихся, как считается, с дониконовых времен или от «истинных священников» до сих пор сохраняются как в общинах у тувинских старообрядцев, так и уральцев, а Великая вода ежегодно «пополняется». Это действие преисполнено для старообрядцев важнейшими смыслами, символизируя преемственность традиции, непрерывность благодати и незавершенность земной жизни в целом. Оно может распространяться и на другие предметы, необходимые для богослужения, например, ладан, который также не должен заканчиваться:

«А не доводят до того, чтобы старый (ладан. - Е. Д.) кончился, добавляют кедровой серы. Добавляют и не доводят до такой степени, что выйдет все... (То есть он тоже располняется что ли? - Е. Д.). Ну, как располняется, ради того, чтобы он не исчез вовсе. Если издержишь его весь, не добавишь, совсем нечем кадить будет» (ПМ, 2018. Сизим, интервью 2).

Существует еще так называемая Малая вода, освящаемая летом, в Спасов день (на Первый Спас). В отличие от Великой может храниться в каждом доме и использоваться для самых различных нужд, например, очищения посуды:

«Она, Малая вода, для того дана, чтобы исправить что-то. Вот бывает мышь попадет в чистую посудину или что-то там попоганится. Вот ей, Малой, исправляют» (ПМ, 2018. Сизим, интервью 2).

Об этом пишет, в частности, А. В. Черных, исследовавший пермских часовенных (Черных, 2008: 88-89, Электр. ресурс).

\footnotetext{
${ }^{1}$ Требник (Потребник) - богослужебная книга, содержащая чинопоследования (сочетание молитв, песнопений и действий), совершаемых в особых случаях, не входящих в состав храмового (общественного) богослужения православной церкви суточного, седмичного и годового кругов. Иноческий (монашеский) требник включает чин на одеяние рясы и камилавки (элементы монашеской одежды), чины пострижения в малую и великую схиму и чин погребения.

${ }^{2}$ Иерей (от греческого «жрец») - рукоположенный священник в православной церкви, представитель духовенства второй ступени христианской церковной иерархии.

${ }^{3}$ Ектения (от греческого - «протяжное, пространное моление») - одна из главных частей православного богослужения, название последовательности молитвенных прошений. Читается диаконом или священником в диалоге с хором. В зависимости от момента и характера службы принимает разные формы. В данном случае речь идет о заупокойной ектении.
} 
Свечи, зажигаемые рядом с покойным, также используются самодельные, из пчелиного воска. Их изготовление контролируется духовными лицами, от которых получается специальное благословение изготовителями из среды воцерковленных старообрядцев. Как в источнике получения свечей и ладана, так и выборе составляющих их материалов, выражается стремление старообрядцев делать все «по старине», «как раньше, без новых введений». Это требует ответственного подхода к подготовке похорон, которая, соответственно, начинается заранее.

\section{«Как тельная рубашка»: подготовка к смерти}

Обычно человек сам заботится о комплекте погребальной одежды, в исключительных ситуациях, в случае внезапной смерти, например, на реке или во время охоты, ее начинают шить после смерти:

«Беспокоиться должен сам, если не сделал, обмывальщики тут же, где он лежит, шьют саван» (ПМ, 2018. Эржей, интервью 1).

Предпочтительнее использование домотканого полотна, определяемого как «чистое, без примесей», так как сделано своими руками из натуральных материалов. Но в настоящее время чаще используется покупная хлопчатобумажная ткань белого цвета, которая «исправляется»:

«Моют на Енисее, читают Исусову молитву. Три раза положено, все по три раза делают у нас» (ПА, 2018. Эржей, интервью 1).

У уральцев в состав мужского погребального костюма раньше обязательно входили длинная белая рубаха, штаны и пояс, женского - рубаха, сарафан, пояс, головной убор, состоящий из «чехлушки» и двух платков («Непременно три покрова должно быть»). Все белого цвета. Теперь нередко в большинстве исследованных групп хоронят в обычной, но обязательно новой одежде. У тувинских старообрядцев бытует более аскетичный и, вероятно, более архаичный комплект, не включающий сарафана и штанов. Однако и в той и в другой группе как отличительный старообрядческий («християнский») признак обязательно называется саван, тогда как «мирские» обходятся без него. Саван представляет собой большой кусок ткани, сшитый углом наподобие капюшона, доходящего до пят или до колен. Сверху, у лицевой части, его края собираются, образуя складки. Исследователи интерпретируют саван как пережиток древней плащевидной одежды типа древнеславянского плаща («плашть или корзно»), сохранившийся в консервативной старообрядческой среде (Фурсова, 1985: 84). Нательный крестик, надеваемый на покойного, должен быть обязательно новым, не использовавшимся при жизни, в идеале - также из натурального материала:

«Крест тоже меняют. Говорят, надо деревянный чтобы был, из кедра. Но это редко у кого есть такой. Но если нет, главное, чтобы новый был» (ПА, 2018. Эржей, интервью 1).

Характерно, что ни одна из деталей смертной одежды не должна завязываться на узел. Узелков не должно быть и на нитке, которой сшиваются между собой куски савана. А. К. Байбурин, анализировавший семантику восточнославянских ритуалов, отмечал, что в технологии изготовления смертного отражается архаическое дохристианское представление о непохожести одежды покойного на одежду живых людей. В противном случае тот мог бы забрать идентичный своему наряд, прихватив заодно и владельца (Байбурин, 1993: 108).

У часовенных, как и у старообрядцев некоторых других согласий, отмечается традиция пеленать покойного («Потом у нас еще пеленают, три креста делают, как связывают»). Узкая белая лента продевается под голову усопшего, а два длинных конца обвиваются вокруг тела, образуя спереди три креста - на груди, там, где сложены руки, на бедрах и на коленях. Некоторые исследователи возводят описанную традицию к язычеству («нить, символизирующая отрезок жизни, отпущенный человеку») (Фурсова, 1985: 85), сами старообрядцы ограничиваются объяснением, что это обычай, принятый издревле, «нашими отцами». Во время полевых 
исследований в других группах на Урале мне приходилось фиксировать и другую народную этимологию, когда пеленание покойного сравнивалось с пеленанием младенца с чистой безгрешной душой. Очевидно, такая трактовка довольно распространена в силу простоты и само собой напрашивающейся аналогии. Например, ее отмечала и Ю. М. Аргудяева при описании дальневосточных старообрядцев (Аргудяева, 2000: 303).

Вместе с покойным в гроб укладывают и непременные атрибуты каждого верующего человека, сопровождавшие его в земной жизни, - подручник и лестовка ${ }^{1}$ из холщовой белой материи, сшитые с соблюдением тех же правил, что и при подготовке смертной одежды - ниткой без узелков, с произнесением молитв. Еще одной особенностью смертной лестовки является запрет на использование в ней прессованной бумаги, которой обычно наполняются изнутри каждое из ее делений. Здесь для этой цели служат только небольшие кусочки дерева (березы).

Встречающийся иногда в старообрядческой среде древний обычай опускать в гроб полотняный мешочек с ногтями усопшего, оческами волос, собиравшимися в течение всей жизни, в котором прослеживают идею собирания, составления целого в конце жизненного пути человека (Топоров, 1983: 240-241), в исследованных группах в настоящее время не фиксируется. Хотя некоторые информанты слышали о нем и характеризуют, как «языческий обычай»:

«Да, это нам говорили, языческое все. Языческий обычай. Зачем это собирать? Не надо» (ПМ, 2015. Тараз, интервью 3);

«Это все бесполезно. Грех это. Куда хошь, туда и бросай. Господь сам все соберет. Сделат человека как было. Он нас не спросит. Никогда не верь. Есть это, делают» (ПМ, 2018. Сизим, интервью 2).

Бывают ситуации, когда в могилу опускают какие-то сакральные предметы, утилизация которых обычным путем невозможна, например, обветшавшую лестовку:

«Лестовку старую, которая поистрепалася, в могилу кладут. Хоть кого хоронят, если старая уже, можно положить» (ПА, 2018. Сизим, интервью 2).

Также, по рассказам уральцев, вместе с умершим хозяином могли опустить в могилу книги или иконы, если у человека не оставалось наследников:

«А потом раньше еще такие книги оставались, у кого были, их вместе с умершим или с умершей зарывали в могилы. Иконы, книги, если некому уже по ним молиться. Вот сколько в земле осталось!» (ПМ, 2014. Нукус, интервью 1).

Прежде обряжения покойного, его тело обязательно обмывают. Воду для этих целей набирают, как у тувинских часовенных, так и уральцев в специальную посудину, которую делают из небольшой тыковки, удалив из нее мякоть. Вода обязательно должна быть проточной («текущей»), ее берут из реки и туда же выливают остатки. В реку также выбрасывают посуду и ложку, которой наливают воду в процессе обмывания:

«Маленькой тыковкой с речки приносят [воду] и обратно в речку. И ложку тоже туда выкидывают. Подальще кидают, чтобы унесло» (ПМ, 2018. Эржей, интервью 1).

Обмывание у старообрядцев - процедура скорее символическая: влажной тряпкой крестообразно проводят по суставам умершего, сопровождая процедуру чтением молитв:

«Это у русских купают. А у нас только крестом. Воды наливают и “Святый крепкий, Святый бессмертный...”. Везде на локтях, здесь. По суставам. Ноги уже нет, только до пояса» (ПМ, 2014. Нукус, интервью 5).

\footnotetext{
${ }^{1}$ Лестовка - распространенный в Древней Руси и сохранившийся у старообрядцев тип четок, в виде плетеной кожаной или тряпичной ленты, воплощает одновременно и лествицу (лестницу) духовного восхождения от земли на небо, и замкнутый круг, образ вечной и не прекращаемой молитвы.

Подручник - небольшой коврик квадратной формы, использующийся старообрядцами при совершении земных поклонов во время богослужения. Сшитые особым образом куски материи на подручнике символизируют важные христианские смыслы (ангельские чины, соборы и т. д.).
} 


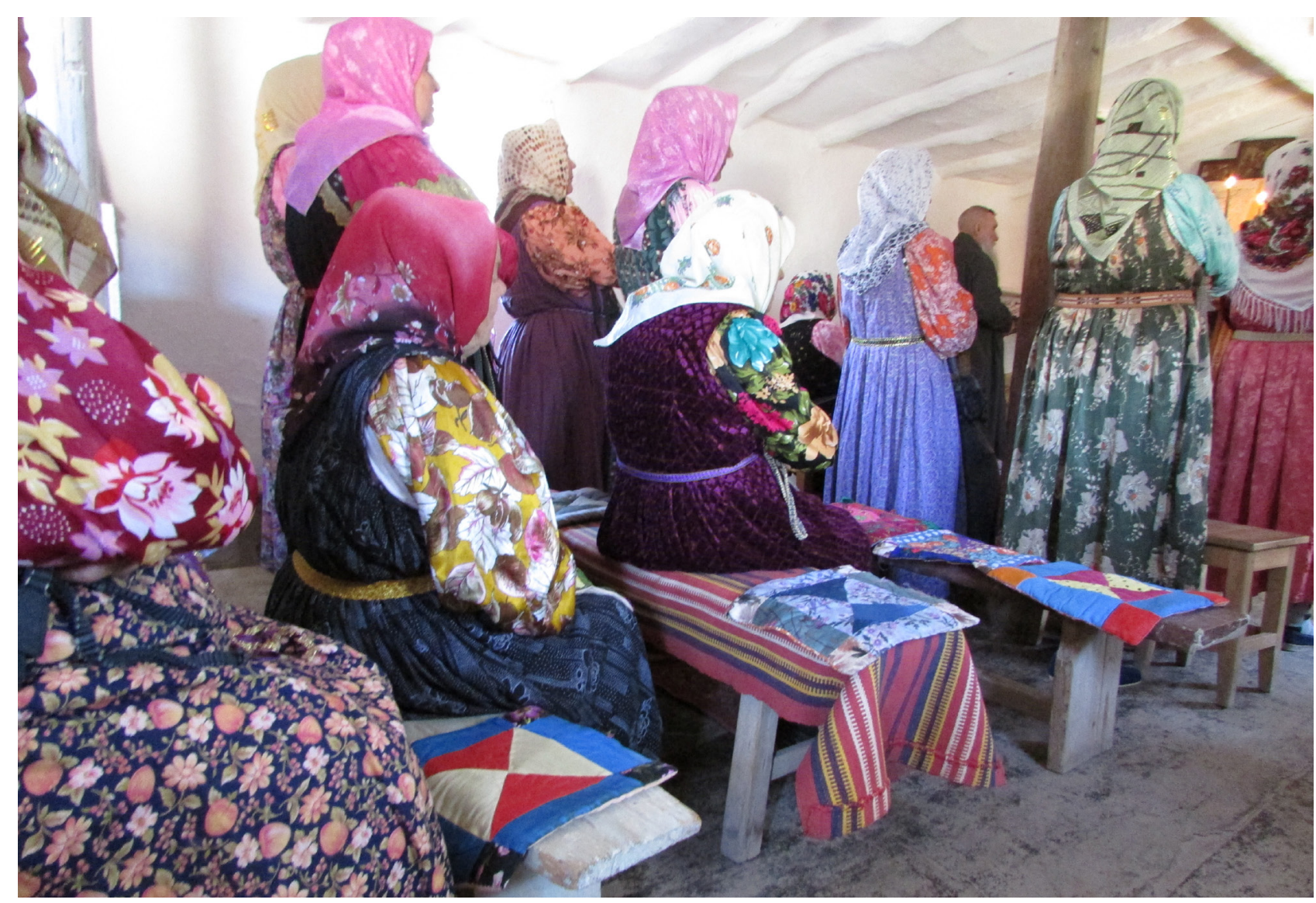

Фото 1. Уральцы. Служба в моленной. Нукус, Каркалпакия. Фото автора, 20142.

Photo 1. Uraltsy. A service in the prayer room, Nukus, Karakalpakia. Photo by the author, 2014.

В соответствии с правилами, мужчину обмывают мужчины, женщину - женщины. Обычно в каждом месте есть группа из нескольких пожилых людей, которую всегда приглашают для этих целей:

«У нас свои обмывальщики, свои читальщики. Они обычно ходят на все похороны»; «Обычно одни и те же пожилые люди это делают. Они уж знают как» (ПМ, 2014. Нукус, интервью 2);

«У нас обычно одни и те же люди этим занимаются. Из пожилых» (ПМ, 2018. Эржей, интервью 1).

После того как внешний вид покойного приводится в соответствие с существующими нормами, тело укладывают на лавку в красном углу, сначала головой к иконам, затем, когда оно перекладывается в гроб, лицом к ним, и, соответственно, ногами от двери. Эта деталь также отмечается как специфичная для старообрядческого похоронного обряда в отличие от «мирского» (Татаринцева, 2006: 118). С момента смерти и до самых похорон над телом усопшего не прерывается чтение молитв. Читают родственники или специально приглашенные для этой цели люди, владеющие книжной грамотой.

У тувинских часовенных до сих пор хоронят в гробах, выдолбленных из цельного ствола дерева. Их называют «домовинами». Такие гробы считаются «правильными», «настоящими» практически у всех старообрядцев, среди которых мне доводилось проводить полевые исследования. При этом, даже не сохраняясь как актуальная практика, изготовление гробов-колод, упоминается как некая особенность именно старообрядческих похорон, бытовавшая раньше, в «старые времена». У уральцев она утрачена, здесь уже давно используют гробы из досок, но как некий показатель их большей или меньшей «правильности» отмечается соединение деталей ящика «на деревянных шипах», то есть без гвоздей. 
О традиции готовить гроб заранее приходилось слышать редко. Могилу, как правило, также копали уже непосредственно перед похоронами. Хотя в нескольких интервью упоминалось и другие ситуации. Например, рассказ бывшей послушницы о монахинях в скитах, которые готовили могилы с осени, чтобы остальным насельницам не пришлось мучиться в суровую сибирскую зиму, прогревая огнем и пробивая мерзлую окаменевшую землю. Помимо чисто практических соображений в таком подходе проявлялись, на мой взгляд, христианские представления о смерти. Для верующего человека подготовка к ней совсем не ограничивается практическими приготовлениями, которые воспринимается лишь как необходимая часть процесса, длящегося всю его жизнь. Быть готовым к смерти следует в любое время, в каждую минуту. Этим обосновывается необходимость вести христианский образ жизни, выполнять все предписания святых отцов. По этой же причине предвидеть собственную смерть дано далеко не каждому:

«Так не дано ему (человеку. - Е. Д.). Раньше-то, давно, дано было преподобным. Вот писано в книгах, какими-то судьбами да Господь их известит. Избранным только дано. Если бы человек знал это, то человек бы пил, гулял, жил бы не как надо, а потом: “Вот я умру скоро и пойду на добрый путь”. А ему что дано? Всю жизнь тебе, мил человек, жить скорбным путем, а не роскошным. Вот это из-за чего! И про страшный суд! А то человек: "Вот скоро страшный суд, надо скорей готовиться”. (То есть, всю жизнь надо быть готовым? - Е. Д.) Каждую минуту! Вот святые отцы говорили: “Я не знаю, вздохну, выдохну или еще нет”. То ли ты вздохнешь и, может, ты умрешь тут. Вот тебе и все. В пословице говорится же, что смерть ближе рубашки. Тельной своёй. На кажду секунду!» (ПМ, 2018. Сизим, интервью 2).

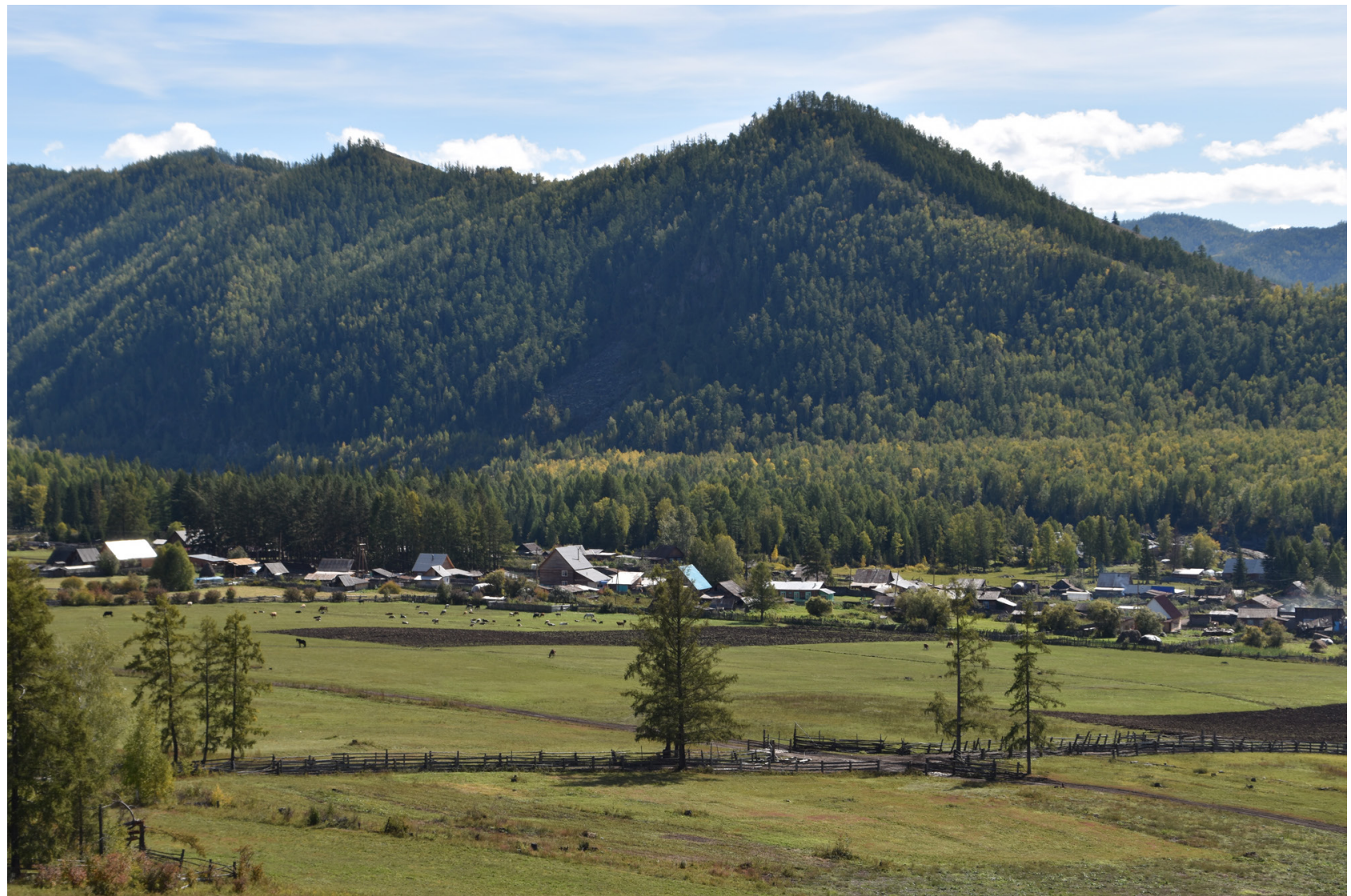

Фото 2. Вид на с. Эржей, Тува. Фото автора, 2018 г.

Photo 3. Old Believers's Cemetery. Uzhep, Tuva. Photo by the author, 2018. 


\section{Пространство мертвых и пространство живых: граница}

От внутренней готовности к смерти, определявшей образ жизни человека, в конечном итоге зависело и то, какими окажутся его проводы в последний путь - будет ли прочитан погребальный чин, станут ли за него молиться члены общины, особенно из соборных (братии) или только родные, и даже то, в какой части кладбища будет погребено его тело. Могилы умерших без покаяния (более года не бывших у исповеди), не соблюдавших постов, не носивших бороды, «табашников» и опойц ${ }^{1}$ располагаются на старообрядческом кладбище в некотором отдалении от остальных. То есть, здесь, как и в других культурах, обнаруживается некоторая универсалия, когда «как и пространство живых, кладбище также обнаруживает религиозные границы» (Ермолин, 2015: 113).

Граница пролегает, прежде всего, между старообрядцами и представителями других религий. При неизбежности бытовых контактов с окружающим населением старообрядцы стараются максимально оградить от внешнего влияния ритуальную сферу и связанные с ней объекты. Поэтому в смешанных населенных пунктах обычно устраиваются отдельные кладбища. Такая ситуация, в частности, актуальна для уральцев, расселяющихся рядом с мусульманами и русскими, относящимися к «никонианской» церкви. В Ужепе, где проживают только часовенные, кладбище также не одно, но это не связано с религиозными границами, а определяется, скорее, территориальной разбросанностью поселения, а также родственными связями. Здесь и в Эржее можно видеть, что могилы родственников группируются вместе, иногда обносятся общей оградой.

При этом, ставить оградки на сами могилы раньше не было принято, ни у тувинских старообрядцев, ни у уральцев. У последних удалось записать объяснения, основным мотивом в которых служат препятствия, с которыми человеку придется столкнуться на Судном дне, - ему будет тяжело выбраться из могилы из-за железной ограды и каменных плит, венок обовьется змеей вокруг шеи, железные ограды потащат человека в ад и т. д.

«Зачем ограды ставить? Не надо. Говорят, покойник не может вылезти из могилы, ограда ему мешает. У нас только кресты стоят и все. И железные кресты тоже нельзя? (А почему? - Е. Д.) Тяжелые. У русских все железные, а у нас нет. Плиты тоже не ложат у нас. Когда, говорят, восстанут живые и мертвые, тогда тяжело будет эту плиту поднимать» (ПМ, 2014. Нукус, интервью 5).

Можно делать различные предположения о семантике и происхождении подобных интерпретаций (например, обратное переосмысление охранительной функции железных предметов и т. п.), в любом случае, очевидно присутствие в них дохристианских представлений, которые могут вызывать и некоторые осуждение в сообществе, воспринимаясь как «домысливание», «придумывание» или «язычество».

Для тувинских часовенных главным авторитетом в утверждении правил и норм, источником знания о том «как положено делать» выступают практики, принятые в скитах и принимающиеся безоговорочно. В подтверждение приведу отрывок из интервью. На вопрос «А кресты с крышей должны быть?» нам ответили:

«С крышей, говорят, что грех у нас. А там (в Дубчесе2. - Е. Д.) как? (Там с крышей. - Е. Д.) Тогда надо крышку. Значит надо. Вот и все. Это крышка ради того, наверно, что крест не

${ }^{1}$ Табашник - курящий человек. Курение, считающееся грехом в православной церкви, у старообрядцев осуждается особенно строго, т.к. табак, привезенный в Россию во времена Петра I, расценивался ими как новшество.

Опойца - человек, умерший от чрезмерного употребления алкоголя.

${ }^{2}$ Дубчесские скиты - известный старообрядческий центр, образовавшийся в бассейне р. Дубчес (левый приток Енисея) конце 1930-х - начале 1940-х гг. в результате переселения зауральских старообрядцев, уходивших от коллективизации. Были разгромлены советской властью в 1950-х гг., насельники подверглись репрессиям. В настоящее время это Туруханский р-н Красноярского края. 
гниет. Вот и все. (А говорили, что грех? - Е. Д.) Говорили. Это я не знаю, может, я сама придумала. Сейчас люди многое другое судят, от себя» (ПМ, 2018. Сизим, интервью 2).

Об отсутствии традиции ставить кресты «с крышами» приходилось слышать и от других наших собеседников, но, видимо, под влиянием Дубчеса, они уже стали появляться на кладбищах. Характерно, что среди уральских старообрядцев именно такая форма намогильного сооружения (с крышей) считается специфической для своего сообщества, и служит еще одним отличительным признаком, отделяющим его от мирских. Описанная ситуация, на мой взгляд, довольно наглядно демонстрирует приведенный выше бартовский тезис об относительности дескриптивных признаков, которые наполняясь новыми значениями, приобретая или теряя «функции маркеров, сигнализирующих о границе» (Барт, 2006: 16) актуализируются или, напротив, утрачиваются.

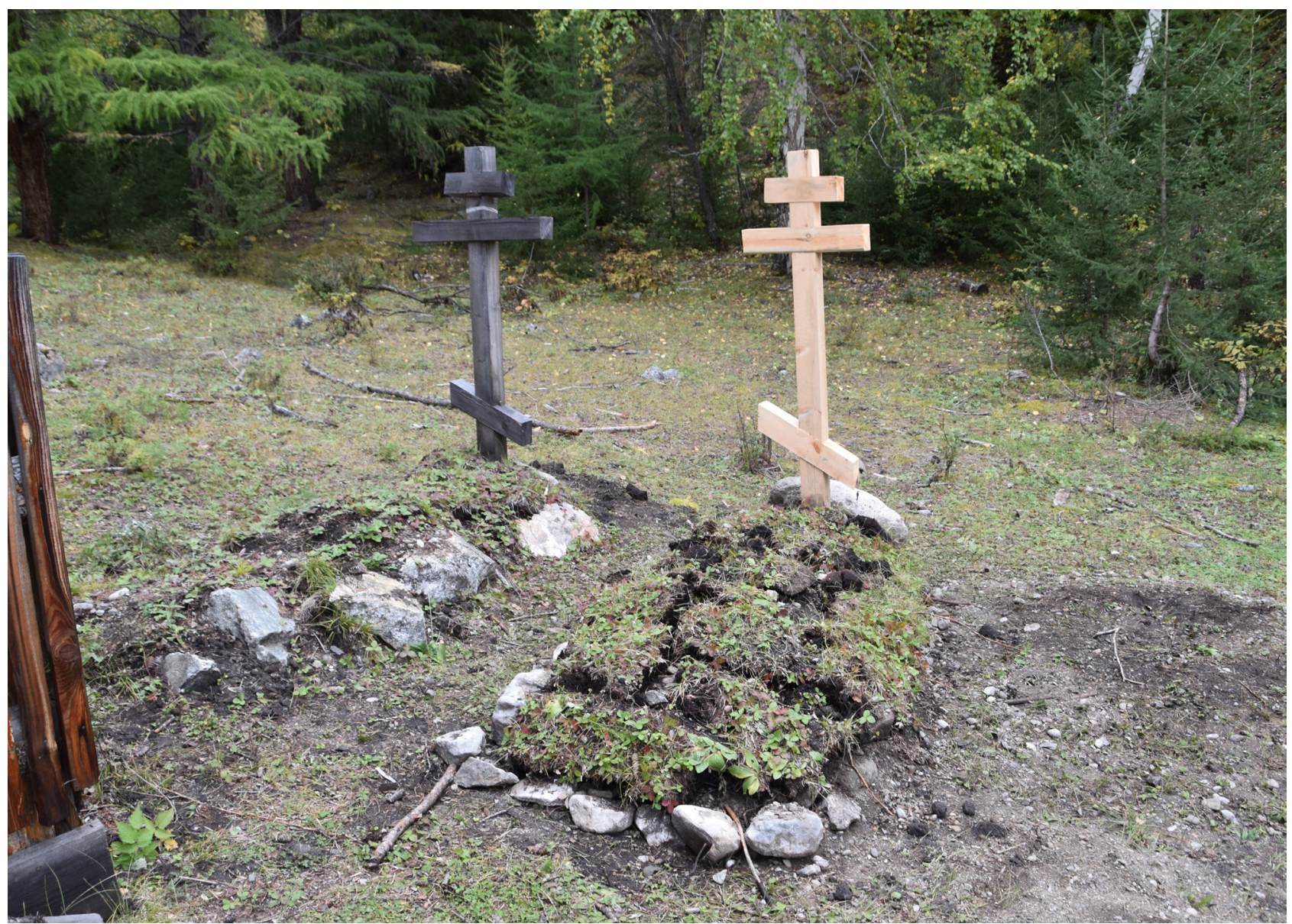

Фото 3. Могилы без ограды. Старообрядческое кладбище в п. Ужеп, Тува. Фото автора, 2018 г. Photo 3. Old Believers's Cemetery. Uzhep, Tuva. Photo by the author, 2018.

Наиболее распространенным у тувинских часовенных в настоящее время является деревянный крест. В верхней его части принято крепить небольшую икону, которая остается здесь 40 дней после погребения, а затем уносится домой. Обновление сгнивших частей или полная замена крестов здесь не порицается, в отличие от практики, принятой в Средней Азии и Казахстане, где после годовщины могилу следует «забыть», то есть не навещать ее и не ухаживать за ней:

«Забыть надо могилу. За год. До года все подавайте, поминайте, а потом забыть эту могилу надо. И кресты должны быть деревянные, сгнили, упали, и все, не трогайте больше» (ПМ, 2014, Нукус, интервью 2); 
«У нас только кресты стоят и все. Мы даже своих родителей потеряли, не знаем, где они находятся уже» (ПМ, 2014, Нукус, интервью 5).

Таким образом, видимые признаки места захоронения постепенно становились незаметными и стирались с поверхности. Даже общая ограда кладбища считалась необязательной, ненужной («А зачем это? Это же тело только там, душа уже в другом месте» (ПМ, 2015. Тараз, интервью 2), хотя захоронение на уральском кладбище иноверцев все же расценивалось как недопустимое.

В настоящее время эта идеальная модель сакрального пространства (кладбище только для «своих») постепенно размывается, в него неизбежно вторгается «чужое»- могилы приезжих жителей или бывших односельчан с железными оградами, советские памятники со звездой, каменные стелы, наконец, не принятые «в старину» надписи с именами и датами жизни на кресте, пока еще воспринимаемые как новшество. То есть некая предметная, видимая граница размывается, хотя граница невидимая, социальная, включающая акциональный план, все еще остается актуальной для обоих исследуемых сообществ. Так, участие в похоронах иноверцев и «мирских» и даже наблюдение за ними со стороны расценивается как тяжкий грех.

При этом, основная разделительная линия с «мирскими» проходит через отношение к вере, греху и покаянию:

«Как старец говорил про мирских людей. “Отче, почему мирские люди не говорят, что мы погибли, живут и живут хладнокровно?” А он и сказал ему, старец то: “Они, - говорит, один раз упали, согрешили, и лежат, и не встают. Не каются об этом! А мы каждую минут обязаны! Согрешили - покаяться, согрешили - покаяться, помолиться. А мирские не беспокоятся о покаянии. Вот из-за чего они лежат”. Они ходят по земле-то, а духовно-то они как мертвые считаются. Раз они не каются» (ПМ, 2018. Сизим, интервью 2).

То есть человек без покаяния оказывается для верующего человека лишь условно живым, мертвецом в живом теле. Обратным же полюсом на этой шкале являются скитники, ведущие праведный образ жизни и отказавшиеся от мирских соблазнов:

«Когда накрывают (посвящают в монахи. - Е. Д.), не пояс на тебя надевают, а ремень. Всю жизнь ремень носим. А ремень обозначает, что он с мертвой скотины, от заколотой, ремень из кожи. Вот также и свое тело мертвым считать при живности, не жалеть его, не мыться в бане, не нежить его» (ПМ, 2018. Сизим, интервью 2).

\section{Поминальная обрядность}

Заключительной составляющей похоронно-поминального комплекса, направленной на сохранение и укрепление родственных и социальных связей, являются поминальные обычаи. Первые поминки устраиваются непосредственно после погребения, когда для участников похорон накрывается стол. Каждый из присутствующих должен отведать по три ложки кутии, которую готовят из разваренных на меду зерен пшеницы. Здесь также присутствует мотив незавершенности:

«Кутию варят, чтобы зерно тверденькое было немного, как будто недоваренное, твердое» (ПА, 2018. Эржей, интервью 1).

Чаша с кутией до начала трапезы находятся в помещение, где совершается соборное моление, во время чтения Чина погребения над ней обязательно кадят.

Остальной набор блюд, подаваемых за поминальным столом, варьируется в зависимости от того, на какой день - «постный» или «скоромный» - приходится обед. Обычно готовятся щи, лапша, различные каши, окрошка, пироги. Из ритуальной еды исключается чай, а у уральцев еще и картофель. Старообрядческие поминки обходятся без спиртного.

Начало и завершение застолья знаменуются молитвой. За столом не принято громко разговаривать и шуметь. Поминальный обед у старообрядцев донес до сегодняшних дней неко- 
торые черты семейной трапезы, известные нам из описаний старинного русского быта. Так, блюда подаются на стол в больших чашах таким образом, чтобы из одной посуды ели несколько человек. Раздаются деревянные ложки, не используются вилки и ножи (Пыляев, 1990: 5-6).

У уральцев сохраняется довольно сложная регламентация относительно поминальной трапезы, касающаяся как подаваемых блюд, так и правил поведения:

«Семь блюд у нас обязательно подают. Соль, вода, хлеб - одно блюдо. Потом пироги пекут, блины. Вот ты садишься за стол, соль, вода, хлеб. Значит дедушка сам чуть-чуть поест, потом скажет: “Благословляю, кушайте”. Потом подают пироги, наверху стоят блины. Эти блины тоже, мы не маслом мажем, а больше делаем орехи, кишмиш через мясорубку крутим, и блины намазываем этим. И потом когда блины режем, не так мы режем как другие. Крестнакрест делаем. Вот блины намазали, и режем вот так крестом. Сначала блины кушаем, блины съели, пироги тоже вот так режем. К пирогам приносят уху. У нас мясом не поминают. Никогда. Только рыбой могут поминать. Приносят уху, пирог ешь, ухой запиваешь. Уху поели, потом кашу какую-нибудь варят. Молочную кашу варят. Когда пост в кашу кладут кишмиш там, туда-сюда. Орехи кладут. Каша вкусная, хорошая получается. Кашу поели, потом подают коравайцы с урюком. А сначала кисель, сладкий кисель. Вот перед киселем, когда кисель подали, чей покойник, их родня всем, кто сидит, подают милостыню» (ПА, 2014. Нукус, интервью 5).

В обязанности родственников умершего входит и раздача милостыни всем участникам похорон, прежде всего тем, кто помогал в их организации - читал молитвы, обмывал и обряжал тело, готовил гроб и копал могилу, нес тело на кладбище. Их награждают кусками материи, полотенцами, предметами одежды, заворачивают еду с поминального стола. У уральцев принято включать в состав милостыни луковицу, которая якобы, прорастая, может вытянуть грешника из ада. У тувинских старообрядцев о такой практике никогда не слышали. В свою очередь, здесь бытует довольно специфический и незнакомый уральцам обычай поминовения младенцев, умерших некрещеными:

«Сорок крестов надо подать, сорок поясков и сорок рубашечек. Сорока разным людям. Да, и стараются, чтобы тайно. Говорят, милостыню подаешь так, чтобы правая рука знала, а левая не знала» (ПА, 2018. Эржей, интервью 1).

Все это свидетельствует о многообразии локальных вариантов обрядности и невозможности составления какого-то единого комплексного описания.

Милостыня не является лишь способом выражения благодарности, она предполагает ответное действие - молитву за умершего. Наиболее достойной истинного христианина считается тайная милостыня, когда приношение, оставляется где-то на видном месте (на крыльце, в воротах, на подоконнике). Обычно оно сопровождается запиской с именем человека, в честь которого совершается дар и за которого просят помолиться. В случае, если речь идет о «неуправленном» (не принявшем причастие) покойнике пишут только имена святых, считающихся заступниками грешных душ перед Богом - Святых Паисия или Уара, Григория Нисского и, конечно, Богородицы. Милостыню принято подавать не только в памятные дни (девятины, сороковины, годины), но и в любое другое время. Импульсом к этому, могут стать, например, сны, в которых покойник жалуется на что-то или каким-то другим способом дает понять родным о необходимости подаяния и молитвы. Нередко в таком сне содержится и прямое указание, что именно следует подать:

«Приснился муж мне, так явно, как живой будто. Идет босой, говорит: “Холодно мне, ноги мерзнут”. Подала носки тогда, связала и подала» (ПМ, 2018. Ужеп, интервью 2).

Одной из особенностей поминального цикла, воспроизводимого в течение года, является его сакральная повторяемость. Различаются частные и календарные поминки. К разряду частных относятся поминания умершего на третий (обычно совпадает с похоронами), девятый, сороковой дни и годины. Входящие в структуру погребального ритуала, они значительно 
расширяют его временные рамки. Сорочины наиболее значимые из них, так как считается, что именно тогда душа, ходившая «по мукам», окончательно покидает землю, отправившись в некое место (светлое или темное), где ей предстоит ожидать Страшного Суда:

«Она (душа. - Е. Д.) сколько прожила на свете, по всему водят ее. Ангели носят. Что где сделала добро, где человеку помогла, где человека погубила. Где грех сотворила с кем. Вот эти 40 дней ей показывают. Это писано есть. По мытарствам ведут. Вот тут и беси бегают, вешают грехи. Если перетянет, то все, с мытарства поведут душеньку в темное место до Страшного суда. Ак если праведная душа, то доведут до престола Христова. Он поклонится, и Господь прикажет - до места, до Страшного суда на место спокойное. Там уже ничего ему. Ни болезни, ни печали, ни воздыхание, но жизнь вечная. Там же не так как здесь, сегодня снег, завтра жарко, потом холодно. Там одно, и одно, и одно. Тепло и светло, и все» (ПМ, 2018. Сизим, интервью 2).

Календарные поминовения, которые называют родительскими днями, имеют другой обрядовый статус, так как связаны не с конкретными похоронами и индивидуальной смертью, а с категорией предков вообще. Уральцы, как было сказано выше, избегают посещать кладбище, тувинские часовенные также делают это не часто, либо на годины конкретного человека, либо во вторник Фоминой недели после Пасхи.

\section{Заключение}

Таким образом, современный старообрядческий похоронно-поминальный комплекс являет собой сложное многослойное явление, представленное разнообразием локальных форм. Реконструкция некого исходного или универсального его варианта не входила в задачу настоящей статьи. Скорее, напротив, описанный материал показал всю относительность подобных попыток в условиях внутренней «несинхронности» вариантов, когда, по выражению О. Седаковой, современное состояние одного оказывается реконструкцией для другого (Седакова, 2004: 27). И вместе с тем, как показывает исследование, те или иные обрядовые практики, способы организации кладбищенского пространства, артефакты и символы обнаруживают важный для рассмотренных старообрядческих сообществ арсенал маркеров, сигнализирующих об актуальной на данный момент групповой границе, дифференцирующей и интегрирующей одновременно.

\section{Благодарности}

В заключение хотелось бы выразить благодарность людям, при помощи и содействии которых стали возможны написание и публикация настоящей статьи. Прежде всего, самим старообрядцам, за их доверие ко мне, за доброту и гостеприимство.

Мои полевые исследования в Туве не состоялись бы без Алены Александровны Стороженко, щедро делившейся со мной своим знаниями, своими связями и контактами и, самое главное, теплом своей души. Спасибо моим друзьям и коллегам, вместе с которыми собиралось «поле», и были проведены незабываемые дни в тувинских поселках: Александру Кострову, Александру Пригарину, Наталье Литвиной, Михаилу Чернову, Петру Алексееву и Цутомо Цукада.

В статье привлекались материалы, полученные во время исследований в Узбекистане (Каракалпакия) и Казахстане, за эту возможность благодарю руководителя проекта РГНФ - Светлану Александровну Иникову и мою коллегу Елену Александровну Агееву.

\section{СПИСОК ЛИТЕРАТУРЫ}

Агеева, Е. А., Данилко, Е. С. (2016) Казаки-уральцы - этнолокальная группа русских в Средней Азии и Казахстане (материалы полевых исследований) / Исследования по прикладной и неотложной этнологии. Вып. 249. М. : ИЭА РАН. 32 с. 
Аргудяева, Ю. В. (2000) Старообрядчество на Дальнем Востоке России. М. : ИЭА РАН. 365 с.

Байбурин, А. К. (1993) Ритуал в традиционной культуре. Структурно-семантический анализ восточнославянских обрядов. СПб. : Наука. 240 с.

Барт, Ф. (2006) Введение // Этнические группы и социальные границы. Социальная организация культурных различий : сборник статей / под ред. Ф. Барта, пер. с англ. И. Пильщикова. М. : Новое издательство. 200 с. С. 9-49.

Данилко, Е. С. (2016) Старообрядцы-уральцы в Средней Азии и Казахстане: взаимоотношения с соседями и социально-культурная адаптация // Вестник антропологии. № 4. С. 22-38.

Ермолин, Д. (2015) Границы конфессионального, этнического и регионального в погребальном обряде албанцев // Археология русской смерти. № 1. С. 100-120.

Покровский, Н. Н., Зольникова, Н. Д. (2002) Староверы - часовенные на востоке России в XVIII-XX вв. М. : Памятники исторической мысли. 471 с.

Пыляев, М. И. (1990) Старое житье. Очерки и рассказы о бывших в отшедшее время обрядах, обычаях и порядках в устройстве домашней и общественной жизни. М. : Русич. 464 с.

Стороженко, А. А. (2015) Конфессиональные миграции старообрядцев как канал межкультурного взаимодействия в Центральной Азии в XIX - начале XX в. // Старообрядчество [Текст] = Old belief : история и современность, местные традиции, русские и зарубежные связи : материалы VI Международной научно-практической конференции, г. Улан-Удэ, 7-8 августа 2015 г. / отв. ред. С. В. Васильева. Улан-Удэ : Издательство Бурятского госуниверситета. 391 c. C. $130-137$.

Седакова, О. А. (2004) Поэтика обряда. Погребальная обрядность восточных и южных славян. М. : Индрик. 320 с.

Судаков, С. А. (2011) Уральские казаки-старообрядцы Аму-Дарьинского оазиса. Уральск : Оптима. 128 с.

Татаринцева, М. П. (2006) Старообрядцы в Туве: историко-этнографический очерк. Новосибирск : Наука. 216 с.

Топоров, В. Н. (1983) Пространство и текст // Текст: семантика и структура / отв. ред. Т. В. Цивьян. М.: Наука. 302 с. С. 240-241.

Фурсова Е. Ф. (1985) Женская погребальная одежда русского населения Алтая // Традиции и инновации в быту и культуре народов Сибири / отв. ред. Л. М. Русакова. Новосибирск : Акад. наук СССР, Ин-т истории, филологии и философии. 142 с. С. 73-87.

Черных, А. В. (2008) «Святая вода» в старообрядческих традициях Пермского Прикамья // Вестник Челябинского университета. № 5. С. 88-92.

Дата поступления: 18.10.2018 г.

\section{REFERENCES}

Ageeva, E. A. and Danilko, E. S. (2016) Kazaki-ural'tsy - etnolokal'naia gruppa russkikh v Srednej Azii i Kazakhstane (materialy polevyh issledovanii) [Ural cossacks, an local ethnic group of Russians in Central Asia and Kazakhstan: Materials of field research]. Issledovaniia po prikladnoi i neotlozhnoi etnologii [Research in applied and urgent ethnology], vol. 249. Moscow, IEA RAS. 32 p. (In Russ.).

Argudiaeva, Yu. V. (2000) Staroobriadchestvo na Dal'nem Vostoke Rossii [Old Belief in the Far East of Russia]. Moscow, IEA RAS. 365 p. (In Russ.). 
Bajburin, A. K. (1993) Ritual v traditsionnoi kul'ture. Strukturno-semanticheskij analiz vostochnoslavianskih obriadov [Ritual in traditional culture. A structural and semantic analysis of East Slavic ceremonies]. St. Petersburg, Nauka. 240 p. (In Russ.).

Bart, F. (2006) Vvedenie [Introduction]. In: Etnicheskie gruppy i sotsial'nye granicy. Sotsial'naia organizatsiia kul'turnykh razlichii [Ethnic groups and social borders. Social organization of cultural distinctions]. A collection of articles / ed. by F. Bart, trans. from English I. Pilshchikov. Moscow, Novoe izdatel'stvo. 200 p. Pp. 9-49. (In Russ.).

Danilko, E. S. (2016) Staroobriadcy-ural'tsy v Srednei Azii i Kazakhstane: vzaimootnoshenia s sosediami i sotsial'no-kul'turnaia adaptatsia [Ural Old Believers in Central Asia and Kazakhstan: relationship with neighbors and sociocultural adaptation]. Vestnik of anthropology, no. 4, pp. 22-38. (In Russ.).

Ermolin, D. (2015) Granitsy konfessional'nogo, etnicheskogo i regio-nal'nogo v pogrebal'nom obriade albantsev [Borders between the confessional, the ethnic and the regional in Albanian funeral ceremony]. Arheologiia russkoi smerti, no. 1, pp. 100-120. (In Russ.).

Pokrovskii, N. N. and Zol'nikova, N. D. (2002) Starovery - chasovennye na vostoke Rossii v XVIII $X X v v$. [Chasovennye ('chapel-going') Old Believers in the east of Russia in the 18th - 20th centuries]. Moscow, Pamiatniki istoricheskoi mysli. 471 p. (In Russ.).

Pyliaev, M. I. (1990) Staroe zhit'e. Ocherki i rasskazy o byvshikh $v$ otshedshee vremia obriadah, obychaiah i poriadkah v ustroistve domashnei i obshhestvennoi zhizni [Old life. Sketches and stories on the ceremonies in days past, on customs and orders in the structure of the house and public life]. Moscow, Rusich. 464 p. (In Russ.).

Storozhenko, A. A. (2015) Konfessional'nye migratsii staroobriadtsev kak kanal mezhkul'turnogo vzaimodeistvia v Tsentral'noi Azii v XIX - nachale XX v. [Confessional migrations of Old Believers as the channel of cross-cultural interaction in Central Asia in 19th and early 20th century]. In: Staroobriadchestvo: istoriia i sovremennost', mestnye traditsii, russkie i zarubezhnye sviazi [Old Belief: history and modernity, local traditions, Russian and foreign relations]. Proceedings of 6th International research conference, Ulan-Ude, 7-8 August 2015 / ed. by S. V. Vasilyeva. Ulan-Ude, Izdatel'stvo Buriatskogo gosuniversiteta. 391 p. Pp. 130-137. (In Russ.).

Sedakova, O. A. (2004) Poetika obriada. Pogrebal'naia obriadnost' vostochnykh i yuzhnykh slavian [Poetics of a rite: Funeral ceremonialism of East and South Slavs]. Moscow, Indrik. 320 p. (In Russ.).

Sudakov, S. A. (2011) Ural'skie kazaki-staroobriadtsy Amu-Dar'inskogo oazisa [Ural Old Believer Cossacks of the Amu-Daryinsky oasis]. Ural'sk, Optima. 128 p. (In Russ.).

Tatarintseva, M. P. (2006) Staroobriadtsy v Tuve: istoriko-etnograficheskii ocherk [Old Believers in Tuva: A historical and ethnographic sketch]. Novosibirsk, Nauka. 216 p. (In Russ.).

Toporov, V. N. (1983) Prostranstvo i tekst : semantika i struktura [Space and text : Semantics and structure] / ed. by T. V. Tsivyan. Moscow, Nauka. 302 p. Pp. 240-241. (In Russ.).

Fursova, E. F. (1985) Zhenskaia pogrebal'naia odezhda russkogo naseleniia Altaia. Traditsii i innovatsii v bytu i kul'ture narodov Sibiri [Women's burial clothes of the Russian population of Alta. Traditions and innovations in life and the culture of the people of Siberia] / ed. by L. M. Rusakova. Novosibirsk, Akad. nauk SSSR, In-t istorii, filologii i filosofii. 142 p. Pp. 73-87. (In Russ.).

Chernykh, A. V. (2008) «Sviataja voda» v staroobriadcheskikh traditsiakh Permskogo Prikam'ya ["Holy water" in Old Belief traditions of the Perm Prikamye]. Vestnik Cheliabinskogo universiteta, no. 5, pp. 88-92. (In Russ.).

Submission date: 18.10 .2018$. 